International Journal of Social Sciences and Humanities
Available online at http://sciencescholar.us/journal/index.php/ijssh
Vol. 2 No. 2, August 2018, pages: 141 154
e-ISSN: 2550-7001, p-ISSN: 2550-701X
https://doi.org/10.29332/ijssh.v2n2.153

\title{
Work-family Conflict on Turnover Intention regarding Work Stress As Intervening Variable
}

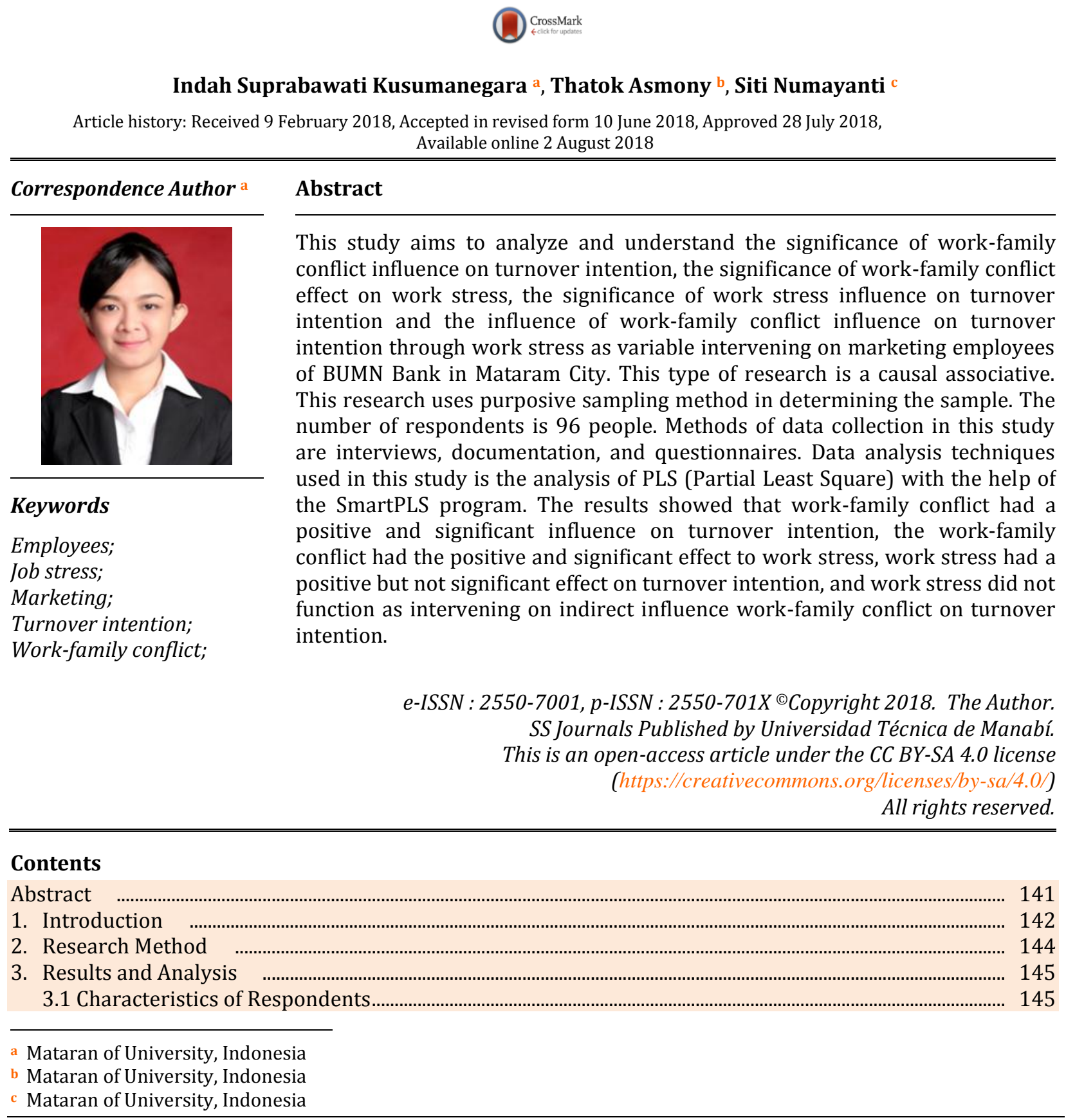




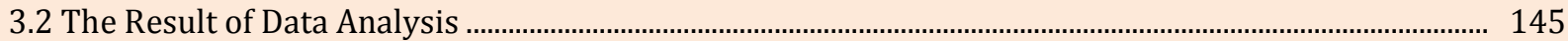

3.3 Result of Model Measurment (outer model) …………………………………….......................................... 145

3.4 Result of Structural Model Measurement (Inner Model) …………………….............................................. 146

3.5 Result of Hypothesis Test .......................................................................................................................................... 147

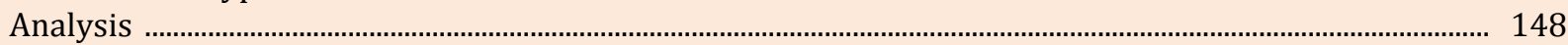

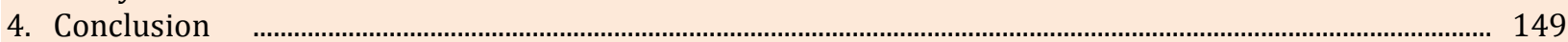

Conflict of interest statement and funding sources................................................................................................ 149

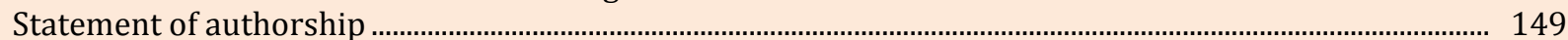

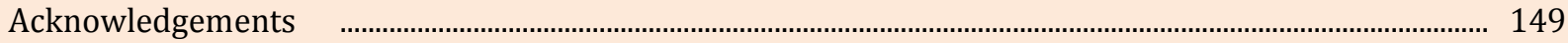

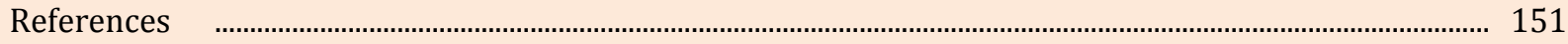

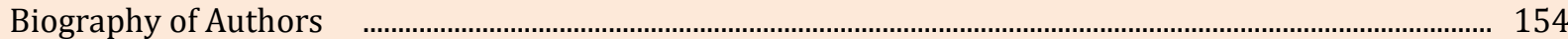

\section{Introduction}

In an organization, an employee is a valuable asset to be retained as it determines the effectiveness of the organization (Octaviani, 2015). Companies should constantly make efforts to retain potential employees to avoid the impact on employee movement. Dessler (2013) states that globalization increases competition in various industries probably impacting on the increasing of organizational pressures to keep expanding in terms of cost efficiency, increasing of employee productivity, and other impacts.

Realizing that the organization performance is highly determined by the conditions and workers' behavior owned by an organization, employees become an important capital for the organization that must be handled properly. The phenomenon often happening is the company performance that has been well performed can be damaged either directly or indirectly by a variety of workers' behavior that is difficult to prevent in which one of the employee behaviors is turnover intention, a desire to get out and find another job that is better than the previous one (Muamarah \& Kusuma, 2012). Robbins and Judge (2009) state that Turnover Intention is the level or intensity of the desire to get out of the company, with reasons for the desire to get a better job.

Referring to Kristanto, et al (2014), the cause of employees having a desire to leave the organization is the high level of Work-Family Conflict on the employee. A work-family Conflict is a form of Interrole Conflict that is the pressure or imbalance of roles between roles in workplace and role in the family (Greenhaus \& Beutell, 1985). Work-family conflict arises when a person performing his role in a job has difficulty to perform his or her role in the family and vice versa. Wicaksono (2016) sees the Work-Family Conflict as the main factor determining the Turnover rate in every organization. When employees experience multi-role as employees and spouse/father/mother, employees will have difficulty to manage time. This role conflict will cause the employee to feel saturated that will lead him or her to often have the intention to leave the company. The affirms that companies should pay more attention to the employees' welfare to prevent the Turnover; for example, by giving an expression of congratulation on the birth of an employee's child. This will make employees feel appreciated and will impact the increase in employee loyalty.

Different results are discovered showing a positive result but insignificant between Work-Family Conflict relationships and Turnover Intention. This research suggests that employees will not leave the organization simply because of the Work-Family Conflict. High unemployment rates in local organizations and fewer employment opportunities elsewhere cause employees to stay in the organization. In addition, research by Agustini (2008) even shows that there is no effect of Work-Family Conflict on Turnover Intention. This research was conducted on 529 employees at the public accounting firm in Jakarta and Bandung. The absence of Work-Family Conflict influence Turnover Intention in this research is because the respondents (employees) are senior employees; therefore, the possibility to get out and find a new job is very slight.

Based on the aforementioned research above, there are 2 studies with slightly different results in which there was no effect of Work-Family Conflict on Turnover Intention. Kusumanegara (2018), this inconsistency results have highly attracted the author to examine the effect of Work-Family Conflict on Turnover Intentions with Work Stress as an intervening variable. Work stress as an intervening variable is expected to bridge the effect of Work-Family Conflict on Turnover Intentions. According to Sutanto and Mogi (2016), the higher work-family conflict of an employee is, the more increasing stress of the employee will be. Work Stress is the pressure in dealing with both job demands and family demands that will cause stress on the individual. Stress 
is an internal state which can be caused by a potentially damaging and uncontrolled physical (body), or environmental, and social situation (Nurmalasari, 2015). Indrawan (2009) states that Work stress is caused by an imbalance between employee personality characteristics with characteristics of the aspects of his or her work and can occur in all work conditions.

\section{Literature Review}

Work and family are two things interconnected and very important for every worker or employee. Both of these are very difficult to integrate if the person is married and has children. Conflicts arise when a person has to make choices between two roles to play (roles in the family and work) so that the person has to perform multiple roles as husband/wife, parents, children and employees. Employees who experience work-family conflict and work stress will cause the high desire of the employee to leave the organization. The results was for Kawiana, et.al. (2018), Ghayyur and Jamal (2012) and Mansoor et al. (2011) state that the higher the conflict and the stress felt by someone, the more intention turnover will be. According to Lathifah and Rohman (2014), they argued that if the level of work stress is already felt by someone, the desire to get out of the company where they work would appear. Work stress has the effect to determine whether to leave or remain in the company. Employees tend to leave the company if they feel stressed about their work (Aydogdu and Asikgil, 2011). Based on the description, the conceptual framework of this research can be presented as follows.

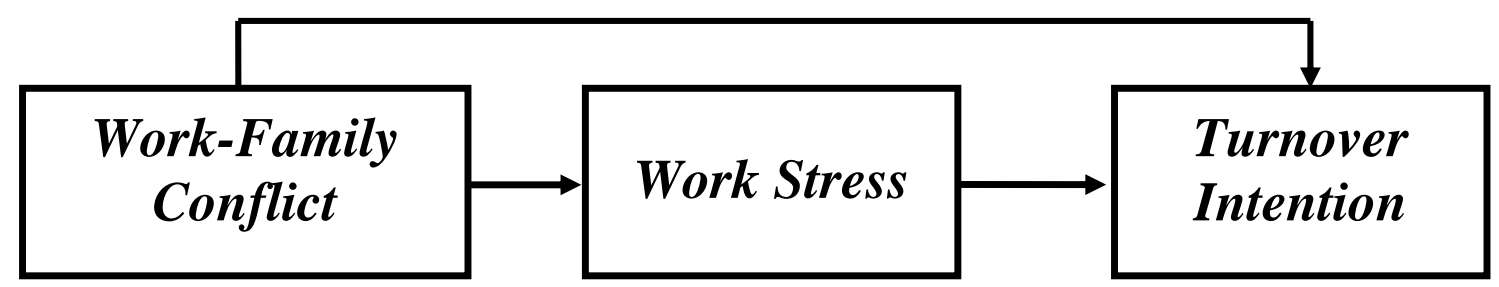

Figure 1. Conceptual Framework of The Study

a) The effect of Work-Family Conflict on Turnover Intentions

Work-Family Conflict can influence Turnover Intentions depending on the dimensions of Work-Family Conflict itself. Previous research was conducted on 355 respondents from four State Universities in Islamabad showing that there was a positive and significant relationship between Work-Family Conflict and Turnover Intentions. Different studies were conducted by Nohe and Sonntag (2014) and Tripathy (2018). They conducted a 5-year study on 665 employees of a private company in Germany. This study shows that Work-Family had a positive and significant effect on Turnover Intentions. Based on the previous research, this study formulates some hypotheses namely:

H1: Work-Family Conflict has a positive and significant effect on Turnover Intention of the employees in the marketing department of PT. Bank Negara Indonesia, Mataram branch.

b) The effect of Work-Family Conflict on Work Stress

The study was conducted by Divara and Rahyuda (2016) on contract employee of Cultural Agency of Bali Province. This study shows that the Work-Family Conflict had an effect on Work Stress. This finding was also supported by a research on women who work as teachers in Ternate conducted by Sabuhari, et.al. (2016). The dual role run by a housewife who also works as a teacher will lead to Work-Family Conflict and leads to the feeling of stress on her as a mother who runs it. Based on these studies, this study formulated a hypothesis namely:

H2: Work-Family Conflict has a positive and significant effect on Work Stress of the employees in the marketing department of PT. Bank Negara Indonesia, Mataram branch.

c) The Effect of Stress Work on Turnover Intentions

Kusumanegara, I. S., Asmony, T., \& Numayanti, S. (2018). Work-family conflict on turnover intention regarding work stress as intervening variable. International Journal of Social Sciences and Humanities, 2(2), 141-154. https://doi.org/10.29332/ijssh.v2n2.153 
The study was conducted on 100 employees of Balikpapan Pertamina Hospital showing that Work Stress had a positive and significant effect on Turnover Intentions. Different research with the same results accomplished conducting research on all security personnel at Korea International Airport, floored that the level of Work Stress was directly proportional to Turnover Intentions level because when employees felt saturated and stressed in their work, it was very vulnerable for the employee to have the intention to get out of the company or move to another company with lower levels of stress. Based on these research results, a hypothesis formulated is:

H3: Work Stress has a positive and significant effect on Turnover Intention of the employees in the marketing department of PT. Bank Negara Indonesia, Mataram branch.

d) The Effect of Work-Family Conflict on Turnover Intentions with Work Stress as an intervening variable

The study on 335 employees from 4 different private universities in Islamabad, Pakistan. The results show that the Work-Family Conflict has a direct and significant positive effect on Turnover Intentions, and Work-Family Conflict has an effect on Job Stress affecting Turnover Intentions. In other words, this study proves that there is an effect of Work-Family Conflict on Turnover Intention with Job Stress as an intervening variable. Based on the explanation above, a hypothesis can be formulated, namely:

H4: Work-Family Conflict has a positive and significant effect on Turnover Intention with Work Stress as an intervening variable on employees of the marketing department of PT. Bank Negara Indonesia, Mataram branch.

\section{Research Method}

The variables of this study consist of independent variables, namely Work-Family Conflict (X), a dependent variable that is Turnover Intention $(\mathrm{Y})$ and Work Stress $(\mathrm{Z})$ as an intervening variable. Each of these variables is a latent variable measured from several indicators. Each indicator consists of several items presented in the questions of the research instrument.

Turnover Intention (X) is the response of marketing staff of State-Owned Banks in Mataram to employees' intention to leave the State-Owned Banks in Mataram consciously and without compulsion measured from 3 indicators namely actively looking for other work, often thinking to get out and willing to not spend a career at work.

Work-Family Conflict (WFC) (Y) is the employee's response to the marketing department of the StateOwned Banks in Mataram for the collision or disturbance felt by the employee from each role to another role that is his or her role in the family and in the workplace measured from 2 indicators of work pressure namely: disrupts family affairs and family pressures that interfere with work affairs.

Work Stress is a response by marketing department employees at State-Owned Banks in Mataram about the excessive workload given by the company to him or her in carrying out the job. Feeling of inability in completing a job due to work environment pressure and pressure from superiors. Work stress can be measured through four indicators namely workload, work time, feedback and responsibility.

230 Employee of the marketing department of State-Owned Banks in Mataram become population in this research of the effect of Work-Family Conflict on Turnover Intention with Work Stress as an intervening variable of marketing department employee at State-Owned Banks in Mataram. To determine the size of the sample, the researcher used non-probability sampling technique with purposive sampling method. Purposive Sampling is a technique for determining samples with certain considerations. The selection of sample criteria is based on the suitability of sample characteristics with the criteria of sample selection that has been determined. The criteria of the sample taken as respondents are as follows:

a) Male / female employees who are married and have children.

b) Employees who have contract status.

c) Employees who have worked for more than 1 (one) year.

Based on these criteria, 96 employees can be considered as qualified samples consisting of 34 employees from the marketing department of Bank BNI and 62 employees in the marketing department of Bank BRI.

The data required in this study include quantitative data expressed in the form of numbers such as data on the number of employees and the number of employees who resigned. Qualitative data in the form of 
descriptions including the research site, a general overview of the company and characteristics of respondents. This study uses several data collection techniques such as questionnaires and observations. Before being used, the research instruments for data collection have firstly tested the validity and reliability. Based on the result of instrument validity test, the instrument is valid because the correlation coefficient value of each variable shows the value above 0.30 ( $r>0.3$ ). Similarly, based on the instrument reliability test, it shows that the instrument is reliable because Alpha Cronbach value of each variable has a greater value than $0.60(\alpha \geq 0.60)$.

This research uses a quantitative approach that is causalistic (Sugiyono, 2009). This research uses explanatory research aiming at explaining causality or relationship between Work-Family Conflict (X), Turnover Intention (Y) and Work Stress (Z) by using PLS (Partial Least Square) method.

\section{Results and Analysis}

\subsection{Characteristics of Respondents}

Based on the results of the study, it showed that the respondents were more male than female respondents with a ratio of $62.5 \%$ : 37.5\%. Employees between the ages of 25 to 30 years more dominated with 60 employees (62.5 percent) than other age ranges did because the average at that age employees was still actively working after marriage on the grounds of increasing income. Based on the last level of education, the employee with Bachelor degree education background dominated with 59 people (61.4 percent) of the total 96 respondents, and based on the duration of work, respondents with 1 to 3 years work dominated with a total number of 40 people (41.6 percent).

\subsection{The Result of Data Analysis}

This research uses the Partial Least Square (PLS) method. In this method, the structural model of the relationship between latent variables is called the inner model. Whereas, measurement is called Outer Model. The stability of the estimation is evaluated by using t-statistics where before analyzing the first test of the empirical model of the study was conducted. Test results can be described as follows:

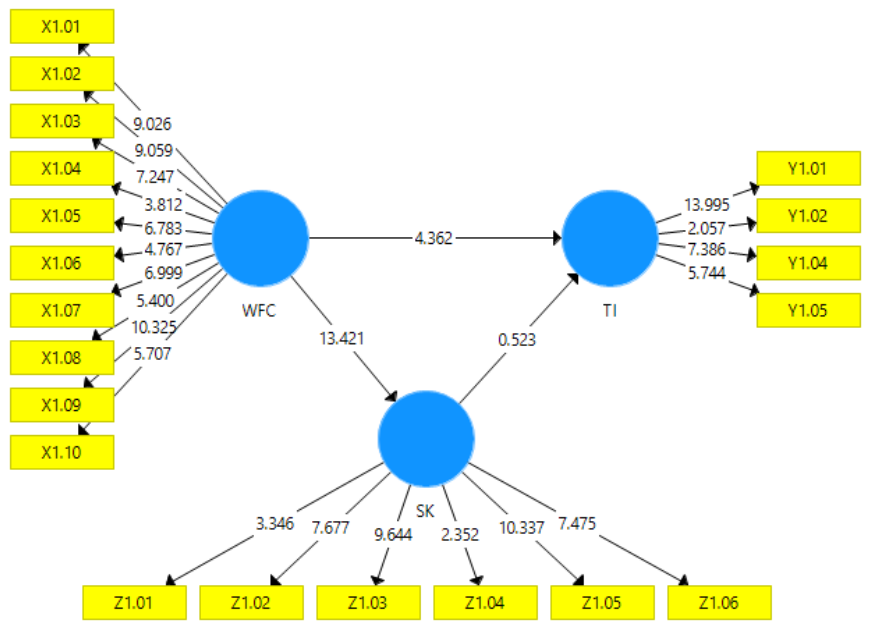

Figure 2. The result of the analysis of PLS

\subsection{Result of Model Measurement (outer model)}

The evaluation of the Outer Model is done by examining the convergent and discriminant validity of the indicators and the composite reliability for the indicator block. The results can be described as follows.

a) Convergent Validity

Kusumanegara, I. S., Asmony, T., \& Numayanti, S. (2018). Work-family conflict on turnover intention regarding work stress as intervening variable. International Journal of Social Sciences and Humanities, 2(2), $141-154$. https://doi.org/10.29332/ijssh.v2n2.153 
By considering the value of outer loadings, the Convergent validity test shows the value of above 0.50 . Therefore, it can be concluded that the requirements of Convergent validity test have been met.

b) Discriminant Validity

Discriminant validity testing is done by comparing the value square root of the average variance extracted (AVE) in each construct with the correlation between other constructs contained in the model. Discriminant validity test results are presented in Table 1

Table 1

The result of discriminant validity test

\begin{tabular}{lccc}
\hline \multicolumn{1}{c}{ Variable } & AVE & $\sqrt{\text { AVE }}$ & Result \\
\hline Work-Family Conflict & 0,341 & 0,584 & Valid \\
Work Stress & 0,358 & 0,598 & Valid \\
Turnover Intention & 0,390 & 0,624 & Valid \\
\hline
\end{tabular}

Based on the test results in Table 1., it can be concluded that the root value of AVE in the research variables meet the discriminant validity measurement requirement because it has value above 0.5 .

c) Composite Reliability

Composite reliability test is done to test the reliability of the instrument in a research model. Composite reliability test results can be seen in Table 2 as follows.

Table 2

The result of a composite reliability test

\begin{tabular}{lc}
\hline \multicolumn{1}{c}{ Variable } & Composite Reliability \\
\hline Work-Family Conflict & 0,835 \\
Work Stress & 0,761 \\
Turnover Intention & 0,705 \\
\hline
\end{tabular}

Based on Table 2 it can be explained that the results of the composite reliability test show the latent variable that is all reliable because it has a composite reliability value greater than 0.7 so that all indicators can be the measuring tool of each construct. Based on the results of the evaluation of the convergent and discriminant validity of the indicators and composite reliability for the indicator block, it can be concluded that the indicators of measurement for variable Work-Family Conflict (X), Turnover Intention $(\mathrm{Y})$ and Work Stress $(\mathrm{Z})$ reliable.

\subsection{Result of Structural Model Measurement (Inner Model)}

The goodness of Fit structural model in Inner Model is tested using predictive-relevance (Q2) value. The R2 value of each endogenous variable in this study can be seen in Table 3 as follows.

Table 3

R-Square

\begin{tabular}{ll}
\hline \multicolumn{1}{c}{ Variable } & R-Square Adjusted \\
\hline Work Stress $(\mathrm{Z})$ & 0,538 \\
Turnover Intention $(\mathrm{Y})$ & 0,325 \\
\hline
\end{tabular}

The predictive-relevance value is obtained by the formula:

$$
\mathrm{Q}^{2}=1-\left(1-\mathrm{R}_{1}^{2}\right)\left(1-\mathrm{R}_{2}^{2}\right) \ldots . .\left(1-\mathrm{Rp}^{2}\right) \text {. }
$$

Based on the above formula, the value of Q-Square in this study is 


$$
Q^{2}=1-\left(1-0,538^{2}\right)\left(1-0,325^{2}\right)=0,36
$$

The value of Q-Square is known as 0.36 or $36 \%$ for Work-Family Conflict as the independent variable that gives effect to Turnover Intention through Work Stress of 36\% indicates that model has predictive relevance because it has a value greater than zero (0), and worthy to be used in prediction. Based on the results of this calculation, it indicates that there are still $64 \%$ of other variables that can affect Turnover Intention of an employee in the marketing department of State-owned Banks in Mataram besides the model that is not studied such as leadership, compensation, organizational culture, burnout, and work environment.

\subsection{Result of Hypothesis Test}

Conducting Hypothesis test by Partial Least Square (PLS) will show seven hypotheses. This test is done by using a t-test (t-test) on each path of influence between variables. Test results from PLS analysis can be seen in Table 4 below.

Table 4

The result of the hypothesis test by partial least square

\begin{tabular}{clcccc}
\hline No & \multicolumn{1}{c}{ Relationship Between Variables } & $\begin{array}{c}\text { Path } \\
\text { Coefficient }\end{array}$ & $\begin{array}{c}\text { T- } \\
\text { statistics }\end{array}$ & p-value & Conclusion \\
\hline 1. & $\begin{array}{l}\text { Work-Family Conflict }(\mathrm{X}) \rightarrow \text { Turnover } \\
\text { Intention }(\mathrm{Y})\end{array}$ & 0,529 & 4,362 & 0,000 & $\begin{array}{c}\text { Positive, } \\
\text { Significant } \\
\text { 2. }\end{array}$ \\
$\quad \begin{array}{l}\text { Work-Family Conflict }(\mathrm{X}) \rightarrow \text { Work } \\
\text { Stress (Z) }\end{array}$ & 0,737 & 13,421 & 0,000 & $\begin{array}{c}\text { Positive, } \\
\text { Significant }\end{array}$ \\
3. $\quad \begin{array}{l}\text { Work Stress }(\mathrm{Z}) \rightarrow \text { Turnover Intention } \\
\text { (Y) }\end{array}$ & 0,070 & 0,523 & 0,601 & $\begin{array}{c}\text { Positive, Not } \\
\text { Significant }\end{array}$ \\
4. $\quad \begin{array}{l}\text { Work-Family Conflict }(\mathrm{X}) \rightarrow \text { Work } \\
\quad \text { Stress (Z) } \rightarrow \text { Turnover Intention }(\mathrm{Y})\end{array}$ & 0,052 & 0,512 & 0,609 & $\begin{array}{c}\text { Positive, Not } \\
\text { Significant }\end{array}$ \\
\hline
\end{tabular}

Table 4 above shows that from 4 (four) relations between variables proposed, 2 (two) relationships among other variables show the significant relationship and 2 (two) relationships among other variables show nonsignificant relationship. The explanation is presented as follows:

a) Test of Hypothesis 1: The effect of Work-Family Conflict on Turnover Intention

Hypothesis 1 states that the Work-Family Conflict has a positive and significant effect on Turnover Intention. The test results on the coefficient parameters between Work-Family Conflict on Turnover Intention showed a positive influence with the coefficient value of 0.529 and the value of $p$-value of 0.000 indicates significant influence. The value of the p-value is below the value of $\alpha=0.10$. Thus, Ha is accepted. This indicates that the Work-Family Conflict has a positive and significant effect on Turnover Intention.

b) Test of Hypothesis 2: The effect of Work-Family Conflict on Work Stress

Hypothesis 2 states that the Work-Family Conflict has a positive and significant effect on Work Stress. The test result on the coefficient of parameters between Work-Family Conflict on Work Stress shows a positive effect of the coefficient value of 0.737 and the value of $p$-value of 0.000 shows significant influence. The value of the $p$-value is below the value of $\alpha=0.10$. Thus, Ha is accepted. It indicates that the WorkFamily Conflict has a positive and significant effect on Work Stress.

c) The result of Hypothesis 3: The Effect of Work Stress on Turnover Intention

Hypothesis 3 states that Work Stress has a positive and significant effect on Turnover Intention. The test result on the parameter coefficient between Working Stress on Turnover Intention shows the positive effect of the coefficient value of 0.070 and the value of the p-value of 0.601 indicates that the effect is not significant. The value of the $p$-value is above the value of $\alpha=0.10$. Thus, Ha is rejected. It means that work stress positively affects the Turnover Intention but not significant.

Kusumanegara, I. S., Asmony, T., \& Numayanti, S. (2018). Work-family conflict on turnover intention regarding work stress as intervening variable. International Journal of Social Sciences and Humanities, 2(2), 141-154. https://doi.org/10.29332/ijssh.v2n2.153 
d) The result of Hypothesis 4: The Effect of Work-Family Conflict on Turnover Intention with Work Stress as Intervening Variable

The amount of indirect effects of Work-Family Conflict variable on Turnover Intention with Work Stress as an Intervening variable is obtained through the result of multiplication of path coefficient (beta) between the direct influence of Work-Family Conflict on Work Stress and Direct Stress Work influence to Turnover Intention on marketing employee of State-Owned Banks in Mataram. The amount of coefficient value of Work-Family Conflict line to Turnover Intention with Work Stress as an Intervening variable is $(0,737 \times 0,070)=0,052$.

\section{Analysis}

\section{a) The Effect of Work-Family Conflict on Turnover Intention}

The results of the data analysis show that the Work-Family Conflict has a positive and significant influence on Turnover Intention. Therefore, the first hypothesis stating that "Work-Family Conflict has a positive and significant effect on Turnover Intention" is accepted. The higher level of Work-Family Conflict felt by employees will have an impact on the employee's intention to get out of the company (Turnover Intention).

The results of this study support the previous research of revealing the positive and significant relationship between Work-Family Conflict and Turnover Intention. This research suggests that employees intend to leave the organization because it has a role conflict problem. In addition, studies also indicated that there was the effect of Work-Family Conflict on Turnover Intention. This indicates that employees experiencing Work-Family Conflict will not survive the organization where they work in today.

b) The effect of Work-Family Conflict on Work Stress

The result of data analysis shows that the Work-Family Conflict has the positive and significant effect on Work Stress, so hypothesis 2 that "Work-Family Conflict has a positive effect on Work Stress" is accepted. The more employees feel the high Work-Family Conflict level, the higher the level of Work stress felt by the employee of the marketing department of State-Owned Banks in Mataram. On the contrary, if an employee feels that having a low Work-Family Conflict level, it will have an impact on the low level of Work Stress felt by the employee of the marketing department of State-owned Banks in Mataram.

The results of this study support the results of previous studies which found that there is a positive and significant influence of Work-Family Conflict on Work Stress where the higher level of Work-Family Conflict is, the higher the level of Work Stress is felt, such as research conducted by Divara (2016) on the contract employee of Bali Provincial Culture Office where the result showed that there was a positive and significant effect of Work-Family Conflict on Work Stress.

\section{c) The effect of Work Stress on Turnover Intention}

The result of data analysis shows that work stress had a positive but not significant effect on Turnover Intention. Thus, the third hypothesis stating "Work Stress has a positive and significant effect on Turnover Intention" is rejected. This means that if the level of Work Stress of the employee of the marketing department of State-Owned Banks in Mataram is high, it will not always have an impact on the appearance of Turnover Intention. In other words, just because feeling stressed, it does not make employees have the intention to get out of the company where he or she works in.

The result of this study does not support the result of previous research finding that there is a positive and significant effect of Work Stress on Turnover Intention, where the higher level of Working Stress perceived, the higher Turnover Intention will be perceived, such as research conducted by Raza, et al (2014) at the University of Pakistan; Yani et.al. (2016) at Bank BRI Denpasar; Wicaksono (2016) at CV. Batik Rara Djonggrang where the results showed that there was a positive and significant effect of Work Stress on Turnover Intention. Research by Sewwandi, et al (2016), Arshadi, et al (2013), Mosadeghrad (2013), showed the same results where there is a positive and significant effect of Working Stress on Turnover Intention. If it is seen from the distribution of respondents' responses to the variable of Work Stress, it seems that work Stress of employee by the employee of the marketing department of State- 
Owned Banks in Mataram is categorized into high level but it has not a great effect on Turnover Intention level. In other words, employees will not leave the company just because they feel Stress with their work. It is because there are several other factors that have been described above that make employees stay in the organization. This fact can be the reason for the different theories and the results of previous research with the results of this study.

d) The Effect of Work-Family Conflict on Turnover Intention with Work Stress as Intervening Variable

Based on the results shown, this study reveals that Turnover Intention is influenced by Work-Family Conflict without Work Stress as an Intervening variable. Employees with Work-Family Conflict will be very susceptible to stress but the height of Work Stress level felt by employees will not affect the level of employee desire to get out of the company where they work in (Rismawan et al, 2014).

The result of this study does not support the result of previous studies finding that there is a positive and significant effect of Work-Family Conflict on Turnover Intention through Work Stress as medium, where the higher level of Work-Family Conflict perceived, the higher the level of work stress will be; consequently, it will have an impact on the increasing of Turnover Intentions in the end, such as research conducted by Raza, et al (2014) at the University of Pakistan showing that there was a positive and significant effect of Work-Family Conflict on Turnover Intention through Work Stress as the medium. If it is viewed from the distribution of respondents' answers to Work-Family Conflict variables it appears that Work-Family Conflict of an employee in the marketing department of State-Owned Banks in Mataram is in the high-level category. The level of Work Stress is also categorized into a high category but it has not a great influence on Turnover Intention level. In other words, employees will have the intention to leave the company simply because they feel they have a Work-Family Conflict without having to feel Stress with their work.

\section{Conclusion}

Based on the results of the research on 96 respondents of employees in marketing staff of State-Owned Banks in Mataram about the effect of Work-Family Conflict on Turnover Intention with Work Stress as an Intervening variable, several points can be concluded as follows:

a) Work-Family Conflict has a positive and significant effect on Turnover Intention. It indicates that the Work-Family Conflict that employees feel has a positive effect on Turnover Intention and its influence is significant. The higher level of Work-Family Conflict that employees perceive to their organization, the higher Turnover Intention will be perceived by employees of the marketing department in StateOwned Banks in Mataram.

b) Work-Family Conflict has a positive and significant effect on Work Stress. It means that the higher level of Work-Family Conflict perceived by the employee, the higher level of work stress will be. Conversely, the lower level of the Work-Family Conflict rate perceived by employees, the lower the level of work stress will be.

c) Work Stress has a positive but not significant effect on Turnover Intention. It means that the higher level of Work Stress does not always impact on increasing Turnover Intention perceived by employees of the marketing department in State-Owned Banks in Mataram.

d) Work stress does not serve as an intervening variable on the effect of Work-Family Conflict on Turnover Intention of employees of the marketing department in State-Owned Banks in Mataram. In other words, Work-Family Conflict is able to significantly influence Turnover Intention of employees without experiencing Work Stress.

Conflict of interest statement and funding sources

The authors declared that (s)/he has no competing interest. The study was financed by personal funding.

Statement of authorship

The authors have a responsibility for the conception and design of the study. The authors have approved the final article.

Kusumanegara, I. S., Asmony, T., \& Numayanti, S. (2018). Work-family conflict on turnover intention regarding work stress as intervening variable. International Journal of Social Sciences and Humanities, 2(2), 141-154.

https://doi.org/10.29332/ijssh.v2n2.153 
Acknowledgments

This research can be resolved with the aid of various parties in the form of guidance, necessary data, criticism and suggestion, and motivation gave incessantly. For my beloved parents, Drs. I Made Pande Swastika State and Desak Putu Kusumawati, S.Pd., Thank you for the guidance during the process of doing and writing this research. The management of PT. Sumber Alfaria Trijaya Branch Lombok, who has been willing to provide data needed during the study. And thanks to all people who cannot be mentioned one by one, who have supported me during conducting this research. 


\section{References}

1. Octaviani, M., Stemmler, I., Lammel, G., \& Graf, H. F. (2015). Atmospheric transport of persistent organic pollutants to and from the Arctic under present-day and future climate. Environmental science \& technology, 49(6), 3593-3602.

View in (Google Scholar)

2. Dessler, A. E., Schoeberl, M. R., Wang, T., Davis, S. M., \& Rosenlof, K. H. (2013). Stratospheric water vapor feedback. Proceedings of the National Academy of Sciences, 110(45), 18087-18091.

View in (Google Scholar)

3. Muamarah, H. S., \& Kusuma, I. W. (2012). Pengaruh iklim etis organisasi dan strees kerja terhadap keinginan berpindah dengan kepuasan kerja. Jurnal BPPK: Badan Pendidikan dan Pelatihan Keuangan, 5 , 77-90.

View in (Google Scholar)

4. Robbins, M., Judge, A., \& MacLachlan, I. (2009). siRNA and innate immunity. Oligonucleotides, 19(2), 89102.

View in (Google Scholar)

5. Kristanto, M. (2014, May). Pendidikan Seni Budaya dan Keterampilan Sebagai Pendidikan Karakter. In Seminar Nasional dan Bedah Buku.

View in (Google Scholar)

6. Greenhaus, J. H., \& Beutell, N. J. (1985). Sources of conflict between work and family roles. Academy of management review, 10(1), 76-88.

View in (Google Scholar)

7. Wicaksono, P., Danoedoro, P., Hartono, \& Nehren, U. (2016). Mangrove biomass carbon stock mapping of the Karimunjawa Islands using multispectral remote sensing. International Journal of Remote Sensing, 37(1), 26-52.

View in (Google Scholar)

8. Agustini, S. S., Queck, A., \& Specht, E. (2008). Modeling of the regenerative heat flow of the wall in direct fired rotary kilns. Heat Transfer Engineering, 29(1), 57-66.

View in (Google Scholar)

9. Sutanto, V., \& Mogi, J. A. (2016). Analisa Pengaruh Work Family Conflict terhadap Stres Kerja dan Kinerja Karyawan di Restoran The Duck King Imperial Chef Galaxy Mall Surabaya.Jurnal Hospitality dan Manajemen Jasa, 4(1), 377-391.

View in (Google Scholar)

10. Nurmalasari, R. (2015). Analisis Efektivitas dan Kontribusi Proses Pelayanan Pengalihan Pengelolaan Serta Pemasukan Pajak Bumi dan Bangunan Terhadap Pendapatan Daerah. Jurnal. jimfeb. ub. ac. id. Diakses, 2. View in (Google Scholar)

11. Indrawan, M., Yabe, M., Nomura, H., \& Harrison, R. (2014). Deconstructing satoyama-The socio-ecological landscape in Japan. Ecological Engineering, 64, 77-84.

View in (Google Scholar)

12. Ghayyur, M., \& Jamal, W. (2012). Work-family conflicts: A case of employees' turnover intention. International Journal of Social Science and Humanity, 2(3), 168. View in (Google Scholar)

Kusumanegara, I. S., Asmony, T., \& Numayanti, S. (2018). Work-family conflict on turnover intention regarding work stress as intervening variable. International Journal of Social Sciences and Humanities, 2(2), $141-154$. https://doi.org/10.29332/ijssh.v2n2.153 
13. Mansoor, M., Fida, S., Nasir, S., \& Ahmad, Z. (2011). The impact of job stress on employee job satisfaction a study on telecommunication sector of Pakistan. Journal of Business Studies Quarterly, 2(3), 50.

View in (Google Scholar)

14. Lathifah, I., \& Rohman, A. (2014). The Influence of Work-Family Conflict on Turnover Intentions with Job Satisfaction as an Intervening Variable on Public Accountant Firms in Indonesia. International Journal of Research in Business and Technology, 5(2), 617-625.

View in (Google Scholar)

15. Aydogdu, S., \& Asikgil, B. (2011). An empirical study of the relationship among job satisfaction, organizational commitment and turnover intention. International review of management and marketing, 1(3), 43-53.

View in (Google Scholar)

16. Nohe, C., \& Sonntag, K. (2014). Work-family conflict, social support, and turnover intentions: A longitudinal study. Journal of Vocational Behavior, 85(1), 1-12.

View in (Google Scholar)

17. Divara, I. G. A. G. K., \& Rahyuda, A. G. Pengaruh work family conflict terhadap stres kerja dan komitmen organisasional pegawai kontrak dinas kebudayaan provinsi bali.

View in (Google Scholar)

18. Sabuhari, R., Soleman, M. M., \& Zulkifly, Z. (2017). Pengaruh work-family conflict terhadap stres kerja (studi kasus pada ibu yang bekerja sebagai guru di kota ternate). Humano, 7(2), 113-125.

View in (Google Scholar)

19. Raza, S., Duquennoy, S., Höglund, J., Roedig, U., \& Voigt, T. (2014). Secure communication for the Internet of Things-a comparison of link-layer security and IPsec for 6LoWPAN. Security and Communication Networks, 7(12), 2654-2668.

View in (Google Scholar)

20.Wicaksono, A., Mursidawati, S., Sukamto, L. A., \& Da Silva, J. A. T. (2016). Rafflesia spp.: propagation and conservation. Planta, 244(2), 289-296.

View in (Google Scholar)

21. Sewwandi, D. V. S., \& Perera, G. D. N. (2016, October). The impact of job stress on turnover intention: A study of reputed apparel firm in Sri Lanka. 3rd International HRM Conference.

View in (Google Scholar)

22. Arshadi, N., \& Damiri, H. (2013). The relationship of job stress with turnover intention and job performance: Moderating role of OBSE. Procedia-Social and Behavioral Sciences, 84, 706-710.

View in (Google Scholar)

23. Mosadeghrad, A. M. (2013). Occupational stress and turnover intention: implications for nursing management. International journal of health policy and management, 1(2), 169.

View in (Google Scholar)

24. Rismawan, P. A. E., Supartha, W. G., \& Yasa, N. N. K. (2014). Peran mediasi komitmen organisasional pada pengaruh stress kerja dan kepuasan kerja Terhadap intensi keluar karyawan. E-Jurnal Ekonomi dan Bisnis Universitas Udayana.

View in (Google Scholar) 
25. Kusumanegara, I. S. (2018). The Analysis of Factors Constructing Employee Productivity in the Operational Field in PT. Sumber Alfaria Trijaya Branch Lombok. International Research Journal of Management, IT and Social Sciences (IRJMIS), 5(1), 55-64.

View in (Google Scholar)

26. Kawiana, I. G. P., Dewi, L. K. C., Martini, L. K. B., \& Suardana, I. B. R. (2018). The influence of organizational culture, employee satisfaction, personality, and organizational commitment towards employee performance. International Research Journal of Management, IT and Social Sciences (IRJMIS), 5(3), 35-45. View in (Google Scholar)

27. Tripathy, M. (2018). Building quality teamwork to achieve excellence in business organizations. International Research Journal of Management, IT and Social Sciences (IRJMIS), 5(3), 1-7. View in (Google Scholar) 


\section{Biography of Author}

\begin{tabular}{|l||} 
Indah Suprabawati Kusuma Negara, born in Mataram June 29, 1995, is the third \\
daughter of three children. She was graduated from SMPN 2 Mataram in 2010 \\
then went to SMAN 5 Mataram by taking the path of acceleration and successfully \\
completed high school within 2 years. In 2012, Indah continued her bachelor \\
degree at Faculty of Economics and Business in Mataram University and gained \\
her bachelor degree in 3.5 years. Currently, she is a student of Magister of \\
Management in Mataram University. Besides, she also works as an employee at PT. \\
Angkasa Pura I (Persero) Branch Lombok International Airport. \\
Email: indah.kusumanegara @yahoo.co.id
\end{tabular}

